\title{
Unwise branding
}

\author{
Equating animal-rights activism with terrorism increases the penalties for offenders and will please \\ many of their victims. But it is not in the interests of science.
}

7 errorist is not a word you throw around lightly. And it is certainly not a word you apply to anyone with whom you would like to have a civil conversation. A US tendency to apply the label to militant activists who are against animal research or genetic engineering slams shut a door that might be difficult to reopen - to researchers' cost.

In a courtroom in Eugene, Oregon, last week, federal prosecutors asked for a 'terrorism enhancement' on the sentencing of ten environmental activists. The activists have admitted to a string of arson attacks in the western United States in the late 1990s and the start of this decade. They torched places where things were done of which they disapproved, including a lab that they believed was growing genetically engineered poplar trees. If the judge applies the requested enhancement, their sentences could be longer and the conditions of their imprisonment more severe.

They are criminals, to be sure. Their arson cost millions of dollars and destroyed scientific work in progress. But although some of their more knuckleheaded actions could easily have accidentally hurt someone, their ethos was to damage property, never to hurt or kill.

Other extreme activists are also being labelled terrorists. Last November, the Animal Enterprise Terrorism Act was signed into law in the United States. It creates tough penalties for damaging property, making threats and conspiring against zoos, animal labs and the like. Leaving aside the merits of this act, its very name enshrines into law the idea that destructive activists are terrorists.

As one of the communities targeted by these activists, scientists may be tempted to embrace this rhetoric. Indeed, many people have personally felt terrified by the actions of the most extreme. But 'terrorist' is a word so debased and loaded by political use that, if it has any meaning at all, it is counterproductive. There is no such objective thing as a terrorist. A criminal is a person who has been convicted of a crime. We can examine a person's records and make an unemotional determination of whether or not they are a criminal. But a terrorist is, in practice, a person who fights for a cause we do not believe in using methods that we do not approve of. Calling someone a terrorist is a value judgement.

It is a value judgement that seems to be increasingly used in the United States since the attacks of 11 September 2001. Indeed, the nation is waging, in official parlance, a "global war on terror". The term is useful politically exactly because it expresses an absolute rejection of a person and their aims. The terrorist label definitively ends any possibility of dialogue. But if there is any hope of bringing closer together those at the extremes of scientific controversies such as animal research and genetic engineering, the various parties must be able to speak to one another.

Although most activists feel that the actions of the criminal few are unproductive and embarrassing, for every
"We should avoid building an unbreachable wall between criminal activists and their victims." activist saboteur with a lighted match there are hundreds of people who are sympathetic to his or her cause. Label that saboteur a terrorist, and you risk alienating all of them. Efforts to bring together defenders and attackers of animal research, such as those by the UK-based Boyd Group, often do not admit those who espouse criminal acts, and that is appropriate. And it leaves open the possibility that an activist who has renounced criminal actions can come to the table. But who will be willing to publicly break bread with a terrorist, reformed or otherwise?

We should avoid building an unbreachable wall between criminal activists and their victims. The judge in this case should reject the call for 'terrorism enhancement'. We must all speak more objectively and calmly.

\section{An unwieldy hybrid}

\section{A draft law will unnecessarily hinder embryo research.}

7 he past few months have seen Britain's politicians tying themselves in knots over the question of whether to allow the creation of 'hybrid' embryos, those made from both human and animal material, for research purposes. Meanwhile, the embryologists who have applied for permission to carry out this research have waited patiently (or perhaps not so patiently) for the verdict.

The outlook initially looked bleak. In December, the government published a policy outline proposing a ban on virtually all forms of hybrid embryos. Medical research organizations reacted angrily, and the House of Commons Select Committee on Science and Technology began working on a report, unveiled in April, criticizing the proposed ban as unnecessary and unfairly restrictive.

Last week, the verdict arrived in the form of the government's draft bill, which seems to be a turnaround on the issue. If it becomes law, the new legislation looks set to allow the creation of 'cybrid embryos' - a particular form of hybrid in which human DNA is placed in an empty animal egg - by the two British research groups that have applied to do it. Assuming that the groups ultimately receive licences to create these embryos, they should give rise to valuable stem cells that could be used to study conditions such as Parkinson's disease.

A range of other techniques also look set to be approved, including the creation of human embryos with animal genes inserted in their DNA, human embryos containing animal cells, and genetically engineered animals with human genes (although the latter will now 